\title{
Stillingsavhengig dyspepsi
}
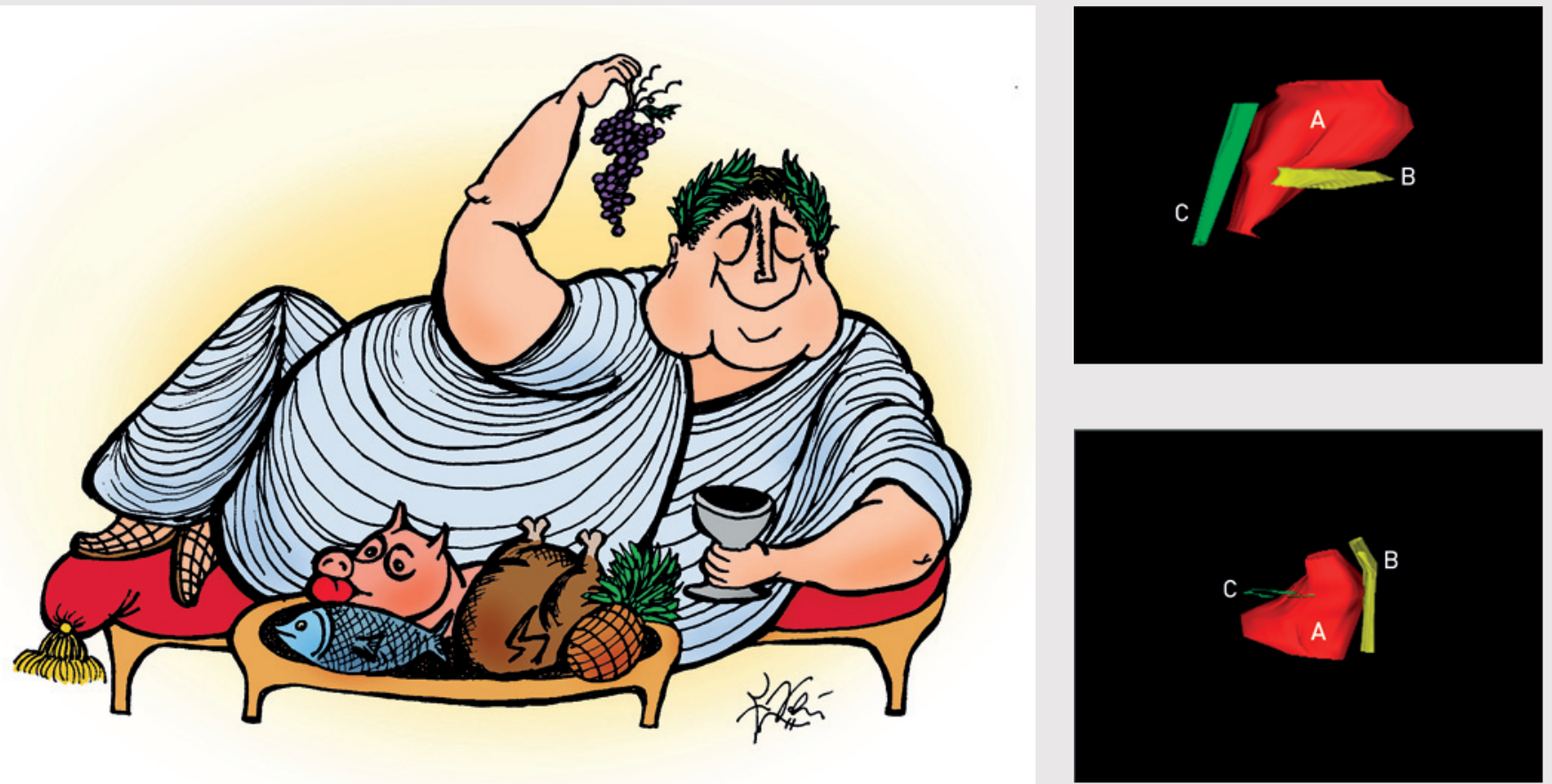

Illustrasjon ๑ Jørgen Valeur

Tyngdekraften påvirker alle kroppens organsystemer (1). I liggende stilling vil magesekkens antrum utvides i leie mot høyre (det øverste bildet) og avlastes i leie mot venstre (det nederste bildet) - her fremstilt ved tredimensjonal ultralydteknikk (A: Antrum, B: Aorta, C: Hud). Distensjon av den distale delen av ventrikkelen har sannsynligvis stor betydning for utvikling av ubehag etter et måltid (2). Slike plager kan lindres ved å legge seg ned i venstre sideleie (3). Kanskje var det nettopp slik de gamle romerne lå under sine etegilder?

\section{Trygve Hausken}

trygve.hausken@helse-bergen.no

Institutt for indremedisin

Universitetet i Bergen

\section{Jørgen Valeur}

Unger-Vetlesens institutt

Lovisenberg Diakonale Sykehus

Trygve Hausken (f. 1951) er professor i gastroenterologi ved Universitetet i Bergen og overlege i fordøyelsessykdommer ved Haukeland universitetssykehus

Forfatter har fylt ut ICMJE-skjemaet og oppgir ingen interessekonflikter.

Jørgen Valeur (f. 1979) er ph.d. og arbeider som assistentlege og forsker ved Klinikk for medisin og Unger-Vetlesens institutt ved Lovisenberg Diakonale Sykehus.

Forfatter har fylt ut ICMJE-skjemaet og oppgir ingen interessekonflikter.
Litteratur

1. Martin-Du Pan RC, Benoit R, Girardier L. The role of body position and gravity in the symptoms and treatment of various medical diseases. Swiss Med Wkly 2004; 134: 543-51.

2. Berstad A. Functional dyspepsia-a conceptual framework. Gut 2000; 47 (suppl 4): iv3-4, discussion iv10.

3. Hausken T. The effect of body position on gastric emptying and postprandial symptoms. Abstract. Neurogastroenterol Motil 2003; 15: 634-5.

Mottatt 3.5. 2012 og godkjent 10.5. 2012. Medisinsk redaktør Siri Lunde. 